\title{
Sowing operation direction and population densities in corn growing
}

\author{
Rafael D. G. Corrêa ${ }^{1}$, Carlos E. A. Furlani ${ }^{1}$, Cristiano Zerbato ${ }^{1}$, Danilo T. de Oliveira ${ }^{1}$, \\ Rafael H. de F. Noronha ${ }^{2} \&$ Newton K. Warikoda ${ }^{1}$ \\ ${ }^{1}$ Universidade Estadual Paulista/Faculdade de Ciências Agrárias e Veterinárias. Jaboticabal, SP, Brasil. E-mail: rafadegraaf@gmail.com (Corresponding \\ author) - ORCID: 0000-0003-3147-1190; eduardo.furlani@unesp.br - ORCID: 0000-0002-1508-5372; cristianozerbato@hotmail.com - ORCID: 0000- \\ 0002-4534-5454; danilotedesco@outlook.com - ORCID: 0000-0003-1875-1489; newton.warikoda@gmail.com - ORCID: 0000-0002-5422-6270 \\ ${ }^{2}$ Universidade Federal do Sul da Bahia/Campus Jorge Amado. Itabuna, BA, Brasil. E-mail: rafael.noronha.agro@gmail.com - ORCID: 0000-0003-0205-9180
}

\begin{abstract}
Among the factors that may influence corn yield are sowing operation direction and plant population, since they alter the shade index between crop rows, and consequently the efficiency of interception of the photosynthetically active radiation by the leaves of plants. The aim of this study was to evaluate the influence of sowing direction and plant populations on P2830VYH hybrid corn yield. The experiment was conducted at the facilities of FCAV-UNESP, latitude $21^{\circ} 14^{\prime} \mathrm{S}$ and longitude $48^{\circ} 16^{\prime} \mathrm{W}$ in Jaboticabal (SP). The treatments were composed of three sowing directions (North-South, NortheastSouthwest, and East-West) and three population densities (40,000, 60,000 and 80,000 plants ha $\left.{ }^{-1}\right)$. The treatment with 80,000 plants ha ${ }^{-1}$ had the lowest cost per sack of corn and profitability $21 \%$ higher than that of the treatment with 60,000 plants ha-1 and $45 \%$ higher than that of the treatment with 40,000 plants ha-1. $^{-1}$. Sowing direction had no influence on grain yield when environmental conditions were favorable to the development of the crop. Lower plant densities lead to higher individual results in relation to the number of cobs, length of cobs and number of grains per row.
\end{abstract}

Key words: Zea mays L., sowing configuration, plant population, grain yield

\section{Sentido da operação de semeadura e densidades populacionais no cultivo do milho}

RESUMO: Entre os fatores que podem influenciar a produtividade do milho estão o sentido da operação de semeadura e a população de plantas, pois esses alteram o índice de sombreamento entre as linhas da cultura, e consequentemente a eficiência da interceptação da radiação fotossinteticamente ativa pelas folhas das plantas. Teve-se por objetivo nesse estudo avaliar a influência do sentido de semeadura e populações de plantas sobre a produtividade do híbrido de milho P2830VYH. O experimento foi conduzido em área da FCAV-UNESP, à latitude de $21^{\circ} 14^{\prime} \mathrm{S}$ e longitude $48^{\circ} 16^{\prime} \mathrm{W}$ no município de Jaboticabal (SP). Os tratamentos estudados foram compostos por três direções de semeadura (Norte-Sul; Nordeste-Sudoeste; e Leste-Oeste) e três densidades

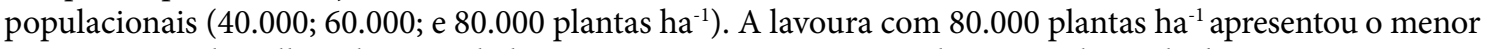
custo por saca de milho, e lucratividade $21 \%$ maior que o tratamento de 60.000 plantas ha ${ }^{-1}$, e $45 \%$ maior que o tratamento de 40.000 plantas ha-1. O sentido da semeadura não exerceu influência sobre a produtividade de grãos quando as condições ambientais foram favoráveis ao desenvolvimento da lavoura. Menores densidades de plantas apresentam maiores resultados individuais em relação ao número de espigas, comprimento de espigas e número de grãos por fileira.

Palavras-chave: Zea mays L., configuração de semeadura, população de planta, produtividade de grãos 


\section{INTRODUCTION}

In relation to the main factors responsible for the success in corn yield (Silva \& Gamero, 2010), the population and plant arrangement stand out. When these factors added to environmental factors are favorable to the development of the crop, the interception of solar radiation by leaves of corn plants influences grain yield (Uate et al., 2015) for optimizing the plant photosynthetic action.

Among the factors that can increase or reduce the interception of solar radiation by plant leaves, it can be mentioned the sowing direction, which changes the indices of shading between the plants in the rows. Karlen \& Kasperbauer (1989) concluded that the sowing direction which led to the best results in the corn crop was the north-south direction, with spacing of $0.76 \mathrm{~m}$ between rows.

There is a lack of studies on the effect of the corn sowing operation in Brazil, and on the latest studies on the subject in the world. However, Brunini \& Turco (2016) in an experiment that occurred in the same region where the present study was conducted stated that the direction of the planting slope affects the growth of sugarcane, which suggests that corn could also share this behavior, since it is within the group of C4 plants.

The hypothesis of this assay is that the correct choice of sowing direction combined with optimal plant density could increase corn yield in low slope plots where it is not necessary to carry out the sowing operation following the level of the land. Based on the information mentioned, the objective of this study was to evaluate the influence of sowing directions and plant populations on the yield of the hybrid P2830VYH and to define, through an economic analysis, the treatment that provides greater profitability.

\section{Material AND Methods}

The experiment was conducted at the facilities of the Faculty of Agrarian and Veterinary Sciences of the São Paulo State University (FCAV-UNESP) in Jaboticabal, São Paulo, Brazil, the coordinates $21^{\circ} 14^{\prime} \mathrm{S}$ and $48^{\circ} 16^{\prime} \mathrm{W}$, with an altitude of $568 \mathrm{~m}$ and slope of $4 \%$, where the relief is defined as smooth undulating. The soil in the area was classified as a typic, moderate, clayey textured eutrophic Red Latosol on smooth undulating relief (EMBRAPA, 2013). The climate of the area is Aw (tropical), according to Köppen's classification adapted by Alvares et al. (2013).

The experimental design was a randomized block design with three replicates, in a $3 \times 3$ factorial, 3 sowing directions (NorthSouth, East-West and Northeast-Southwest) (Figure 1) and 3 population densities $\left(40,000,60,000\right.$, and 80,000 plants ha $\left.{ }^{-1}\right)$. Fertilization with $300 \mathrm{~kg} \mathrm{ha}^{-1}$ of the NPK formulation 8-28-16

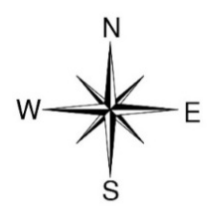

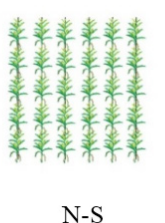

$\mathrm{N}-\mathrm{S}$

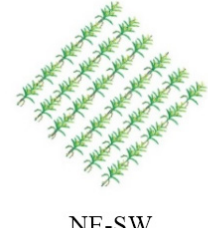

$\left(45^{\circ}\right)$

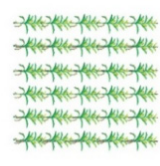

E-W
Figure 1. Sowing and schematic directions of the experimental area was applied through surface broadcast and plots with $36 \mathrm{~m}^{2}$ were used for each treatment, totaling 27 plots where 5 central rows were evaluated.

To determine the direction of sowing, an analogue compass G453 model and three wooden models were used to determine the positioning of the seeds within the correct spacing for each population density. The experiment used the Pioneer ${ }^{\circ}$ brand corn hybrid P2830VYH with Leptra ${ }^{\circledast}$ insect protection technology, which is super early with high production potential and a recommended population of 60-65 thousand plants ha ${ }^{-1}$ in the lowlands (between 400-700 m altitude).

Six 6-m long rows were sown manually at $0.45 \mathrm{~m}$ spacing between rows and the seeds were placed at $0.05 \mathrm{~m}$ depth. The manual control of weeds was performed when the plant had four leaves, given by manual weeding of the plots. Top dressing fertilization was carried out when the corn had six leaves. The applied dose was based on the recommendation of the Technical Bulletin 100 - IAC, corresponding to $266 \mathrm{~kg} \mathrm{ha}^{-1}$ of manually applied urea, totaling $120 \mathrm{~kg} \mathrm{ha}^{-1}$ of $\mathrm{N}$ (Raij et al., 1996).

The monthly average precipitation varied throughout the cycle and exceeded by $293 \mathrm{~mm}$ the water demand of the crop, which is $600 \mathrm{~mm}$ throughout the crop growth (EMBRAPA, 2010). However, water availability decreased during the filling of grains in February and March, when its monthly values were approximately $120 \mathrm{~mm}$, compared to the $200 \mathrm{~mm}$ available in the months characterized by the vegetative growth of the crop, which may have limited the filling of the grains (Figure 2A).

The temperature remained with minimum variation throughout the production cycle, being close to the recommended temperature, between 24 and $30^{\circ} \mathrm{C}$ (Figure $2 \mathrm{~A}$ ). Temperatures below $15.5^{\circ} \mathrm{C}$ and above $32^{\circ} \mathrm{C}$ may cause losses in crop yield (Streck et al., 2009; Galon et al., 2010). The days

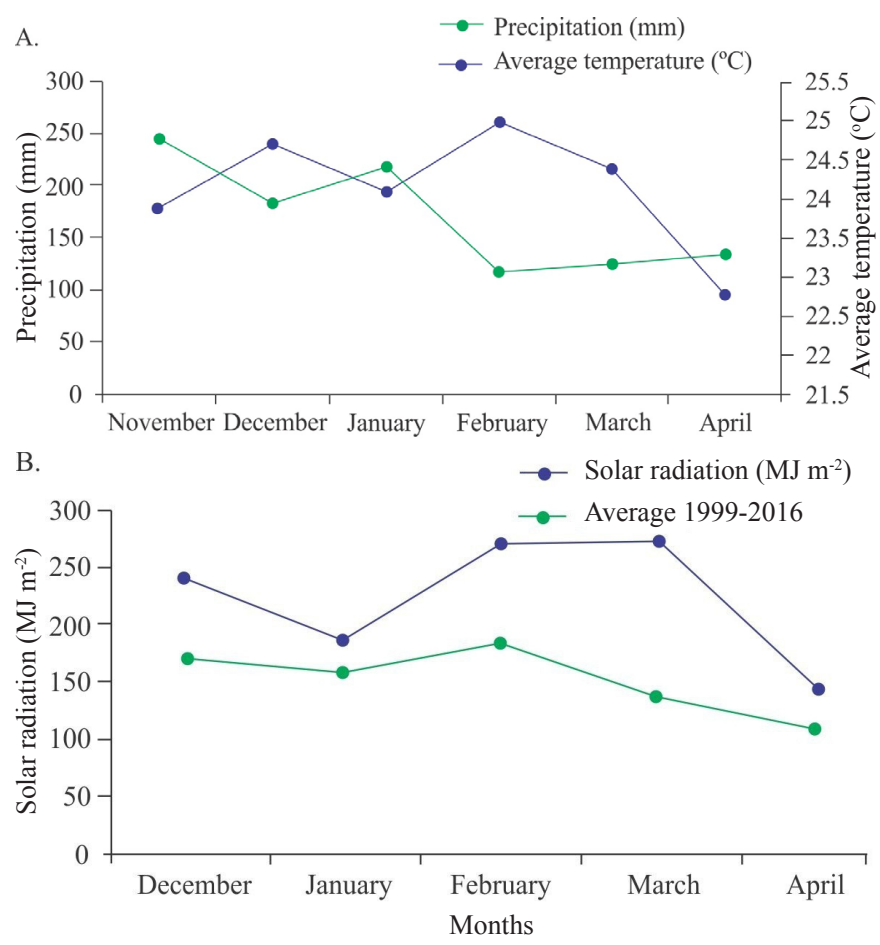

Figure 2. Monthly average preciptation $(\mathrm{mm})$ and monthly average temperature $\left({ }^{\circ} \mathrm{C}\right)(\mathrm{A})$; $[\mathrm{B}]$ monthly total solar radiation $\left(\mathrm{MJ} \mathrm{m}^{-2}\right)$ (B) along the experimental period 
provided optimal conditions of solar radiation, being above the recorded average of the period from 1999 to 2016 in the same place (Figure 2B). According to EMBRAPA (2010), a reduction of 30 to $40 \%$ in radiation is required for long periods in order to reduce yield reduction caused by this factor.

At the end of the flowering phase, five plants of each plot were evaluated for: plant height, stem diameter, number of cobs and leaf area (leaf area evaluation was performed using an optical scanner, where all the leaves of the plants were sampled and the result was obtained in $\mathrm{cm}^{2}$ ).

Once $22 \%$ grain moisture was reached, the spikes were manually harvested along $5 \mathrm{~m}$ from the four central rows of each plot to evaluate yield. Five spikes per plot were evaluated. The following data were collected: spike diameter and length, cob diameter, number of rows of grains, number of grains per row and mass of 1000 grains. Subsequently, the spikes harvested in each plot were threshed and the grains were weighed. The moisture was corrected to $13 \%$ and the corrected mass was extrapolated to obtain yield per hectare.

The data were submitted to the Ryan Joiner normality test and, when normal, to analysis of variance by Snedecor's F statistic at 0.05 level of significance, and when significant submitted to the Tukey test at 0.05 level of significance using the statistical software Agrostat (Barbosa \& Maldonado Júnior, 2010). An economic analysis was performed based on the table of corn production costs (IMEA, 2016) for the 2016/2017 harvest (Table 1) and on the yield results of each treatment in order to highlight the most lucrative treatment.

To estimate the cost of each treatment, the value of the seeds used was added to the other costs obtained based on the production costs informed by the IMEA. The profitability calculation was based on the $60-\mathrm{kg}$ sack in the month of May 2016, when the cereal had already been harvested, and had the price set at $\mathrm{R} \$ 51.48$. The value of the hybrid seed used was set at R\$ 620.00 per sack, which contained 60,000 seeds.

\section{Results AND Discussion}

Statistical analysis of the data presented significance of the results only for the plant population factor (Table 2). Sowing direction had no influence on the evaluated variables, and this can be attributed to the optimal conditions in relation to the solar radiation available in the region and to the high capacity of C4 plants to absorb solar radiation. In addition, since corn was manually sown and consequently obtained an equidistant seed distribution within the treatments, the plants were well distributed in the cultivation row, without self-shading. Another factor to be considered is the leaf area because, when

Table 1. Corn production for the Southeast region without the cost with seeds in the 2016/2017 harvest

\begin{tabular}{|c|c|c|c|c|c|c|}
\hline \multicolumn{2}{|c|}{ Variable costs } & \multicolumn{3}{|c|}{ Fixed costs } & \multicolumn{2}{|c|}{ Total } \\
\hline ECC & OVC & $\overline{F E}$ & D & OFC & LC & TC \\
\hline \multicolumn{7}{|c|}{$\mathbf{R} \$$} \\
\hline 1159.54 & 774.97 & 103.93 & 75.01 & 2.64 & 340.64 & 2456.73 \\
\hline
\end{tabular}

Table 2. Summary of F test for all main effects and interaction for sowing direction and plant population for the evaluated variables

\begin{tabular}{|c|c|c|c|c|c|c|}
\hline \multirow[b]{2}{*}{ Variables } & \multicolumn{3}{|c|}{ F test } & \multirow[b]{2}{*}{ SD } & \multirow[b]{2}{*}{$\begin{array}{l}\text { CV } \\
(\%)\end{array}$} & \multirow[b]{2}{*}{ RJ } \\
\hline & $\begin{array}{l}\text { Direction } \\
\text { (D) }\end{array}$ & $\begin{array}{l}\text { Population } \\
\text { (P) }\end{array}$ & $\begin{array}{c}\text { Interaction } \\
\text { D X P }\end{array}$ & & & \\
\hline PLheight & $0.84^{\mathrm{ns}}$ & $16.82^{\star \star}$ & $1.69^{\text {ns }}$ & 0.05 & 2.42 & 0.99 \\
\hline StD & $0.06^{\mathrm{ns}}$ & 28.31 ** & $1.13^{\mathrm{ns}}$ & 1.20 & 4.69 & 0.99 \\
\hline L. A. & $2.51^{\mathrm{ns}}$ & $2.15^{\mathrm{ns}}$ & $0.63^{\text {ns }}$ & 803.79 & 13.52 & 0.96 \\
\hline ANSP & $0.05^{\mathrm{ns}}$ & $27.79 * \star$ & $0.40^{\mathrm{ns}}$ & 0.18 & 11.94 & 0.98 \\
\hline SPdiameter & $2.39^{\text {ns }}$ & $2.77^{\mathrm{NS}}$ & $1.93^{\text {ns }}$ & 1.00 & 2.01 & 0.98 \\
\hline COBdiameter & $0.79^{\text {ns }}$ & $2.83^{\mathrm{ns}}$ & $0.93^{\text {ns }}$ & 1.78 & 6.17 & 0.80 \\
\hline SPlength & $0.35^{\mathrm{ns}}$ & $11.05^{\star \star}$ & $1.22^{\mathrm{ns}}$ & 0.68 & 4.20 & 0.96 \\
\hline N. G. R. & $1.15^{\mathrm{ns}}$ & $7.14^{\star \star}$ & $0.06^{\mathrm{ns}}$ & 1.77 & 4.96 & 0.99 \\
\hline N.R. S. & $0.78^{\mathrm{ns}}$ & $1.24^{\mathrm{ns}}$ & $0.15^{\mathrm{ns}}$ & 0.63 & 3.784 & 0.98 \\
\hline G. M. & $1.13^{\text {ns }}$ & $4.04^{*}$ & $2.29^{\text {ns }}$ & 2.66 & 8.548 & 0.98 \\
\hline Y & $0.06^{\mathrm{ns}}$ & 10.66 ** & $2.39^{\text {ns }}$ & 1032.50 & 12.43 & 0.98 \\
\hline
\end{tabular}

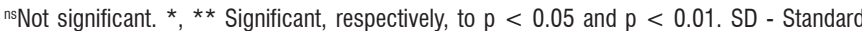
deviation, CV - Coefficient of variation; RJ - Ryan Joiner Normality Test; PLheight - Plant height; StD - Stem diameter; L. A. - Leaf area; ANSP - Average number of spikes per plant; SPdiameter - Spike diameter; COBdiameter - Cob diameter; SPlength - Spike length; N. G. R. - Number of grains per row; N. R. S. - Number of rows per spike; G. M. - Grain mass; Y. - Yield

it is larger, there is optimization of the interception of solar radiation, but it did not differ between treatments. In other less favorable conditions this factor may influence the results (Kasperbauer \& Karlen, 1994).

In the results of plant height and stem diameter (Table 3), it was observed that the two variables have an inverse behavior as a function of the plant populations, and the height is lower in the treatment with a population of 40 thousand plants ha- ${ }^{-1}$ in comparison to other treatments, because the treatment with low population density has plants that do not compete with each other for nutrients, luminosity and water because they are more spaced apart.

The results presented corroborate those found by Balbinot Júnior \& Fleck (2005), who affirm that the increase of plant density causes, among other factors, increase in the height of the crop and reduction in stem diameter. Taller plants with a smaller stem diameter are more susceptible to lodging, which may hamper mechanized harvesting.

Number of spikes per plant decreased with an increase in population density, which according to Pereira (1991), may be because when the density of plants is low, compensation occurs through the increase in the number of spikes, and variation in spike size, which may in some cases minimize differences in yield at different plant populations.

Length of the spike exhibited a difference with the increase of the population density, which may have happened due to the greater availability of water and nutrients per plant provided to

Table 3. Relation of the means of variables that were significantly affected according to the analysis of variance

\begin{tabular}{lccc}
\hline \multirow{2}{*}{ Variables } & \multicolumn{3}{c}{ Plant density (plants ha $\mathbf{~}^{-1}$ ) } \\
\cline { 2 - 4 } Plant height $(\mathrm{m})$ & $\mathbf{4 0 , 0 0 0}$ & $\mathbf{6 0 , 0 0 0}$ & $\mathbf{8 0 , 0 0 0}$ \\
Stem diameter $(\mathrm{mm})$ & $2.11 \mathrm{~b}$ & $2.20 \mathrm{a}$ & $2.25 \mathrm{a}$ \\
Average number of spikes per plant & $27.54 \mathrm{a}$ & $26.30 \mathrm{a}$ & $23.36 \mathrm{~b}$ \\
Spike length $(\mathrm{cm})$ & $1.82 \mathrm{a}$ & $1.51 \mathrm{~b}$ & $1.18 \mathrm{C}$ \\
Number of grains per row & $16.88 \mathrm{a}$ & $16.37 \mathrm{a}$ & $15.40 \mathrm{~b}$ \\
1000 grain mass $(\mathrm{g})$ & $37.15 \mathrm{a}$ & $35.91 \mathrm{ab}$ & $34.02 \mathrm{~b}$ \\
Yield $\left(\mathrm{kg} \mathrm{ha}^{-1}\right)$ & $31.16 \mathrm{ab}$ & $33.05 \mathrm{a}$ & $29.47 \mathrm{~b}$ \\
\hline
\end{tabular}

Means followed by the same letter in the row for each variable do not differ significantly by the Tukey test at 0.05 probability level 
the population of 40,000 plants, besides not occurring shading of one plant on the other, characteristic of densely planted crops, and thus allowing the plant to optimize its ability to convert solar radiation into carbohydrates.

In relation to the number of grains per row, it was observed that the densely planted crop resulted in lower number for this factor, which is directly related to the length of spikes. In general, increasing population or any stress on the crop reduces the number of rows and grains per row, since the plant tends to abort the grains of the tip of the spike, making it shorter when the crop has less nutrients or water per plant (Brachtvogel et al., 2009).

Grain mass was higher in the population of 60,000 plants ha- ${ }^{-1}$, because this population has better ratio of nutrients per plant than the other studied populations. These results corroborate with Demétrio et al. (2008), who concluded that crops with density of 50,000 to 70,000 plants ha ${ }^{-1}$ produce more grain mass compared with larger populations.

Although the population of 40,000 plants shows better results per plant, as observed in the previous tables, the population of 80,000 plants ha-1 obtained higher yield. This fact occurs due to greater number of plants present in this treatment because, despite showing lower yields if plants are considered individually, collectively they produce more grains. The results are similar to those found by Farinelli et al. (2012), which verified yield increase in populations of 60,000 and 80,000 plants ha-1.

According to the results of yield related to total cost of production and profitability, the treatment of 80,000 plants ha $^{-1}$ stood out showing higher profitability than the other treatments, and the additional cost with seeds was diluted in yield (Table 4). Therefore, although it obtained the highest total cost, the crop planted at highest density showed lowest cost per sack of corn production, and its profitability was $21 \%$ higher than that of the treatment with 60,000 plants ha ${ }^{-1}$, and $45 \%$ higher than that of the treatment with the lowest plant density $(40,000)$.

Table 4. Economic analysis of treatments in Reais

\begin{tabular}{|c|c|c|c|}
\hline \multirow{2}{*}{ Costs } & \multicolumn{3}{|c|}{ Population densities } \\
\hline & 40,000 & 60,000 & 80,000 \\
\hline Costs with seeds ha-1 & $\mathrm{R} \$ 413.33$ & $\mathrm{R} \$ 620.00$ & $\mathrm{R} \$ 826.66$ \\
\hline Total costs ha ${ }^{-1 \star}$ & $\mathrm{R} \$ 2870.06$ & $\mathrm{R} \$ 3076.73$ & $\mathrm{R} \$ 3283.39$ \\
\hline Yield $\left(s c\right.$ ha-1$\left.^{-1}\right)$ & $\mathrm{R} \$ 120.27$ & $\mathrm{R} \$ 137.11$ & $\mathrm{R} \$ 157.66$ \\
\hline Cost sc ${ }^{-1}$ & $\mathrm{R} \$ 23.86$ & $\mathrm{R} \$ 22.43$ & $\mathrm{R} \$ 20.82$ \\
\hline Gross income ha-1 & $R \$ 6191.50$ & $\mathrm{R} \$ 7058.63$ & $R \$ 8116.56$ \\
\hline Net profit ha-1 & $\mathrm{R} \$ 3321.44$ & $\mathrm{R} \$ 3981.90$ & $\mathrm{R} \$ 4833.17$ \\
\hline
\end{tabular}

* Value of the seeds used in the experiment plus the other costs established by the table of IMEA (2016), sale price $\mathrm{R} \$ 51,48 \mathrm{sc}^{-1}$

\section{Conclusions}

1. Sowing directions have no influence on grain yield when the conditions are favorable to crop development.

2. Lower plant densities lead to higher individual results in relation to: number of spikes, length of spikes and number of grains per row; besides producing shorter plants and with thicker stems.

3. The plant densities which led to the highest grain yields were 60,000 and 80,000 plants $\mathrm{ha}^{-1}$, so it is recommended to use the latter, since its profitability is $21 \%$ higher than that of the plant density of 60,000 plants $\mathrm{ha}^{-1}$.

\section{Literature Cited}

Alvares, C. A.; Stape, J. L.; Sentelhas, P. C.; Gonçalves J. L. de M.; Sparovek, G. Köppen's climate classification map for Brazil. Meteorologische Zeitschrift, v.22, p.711-728, 2013. https://doi. org/10.1127/0941-2948/2013/0507

Balbinot Júnior, A. A.; Fleck, N. G. Competitividade de dois genótipos de milho (Zea mays) com plantas daninhas sob diferentes espaçamentos entre fileiras. Planta Daninha, v.23, p.415-421, 2005. https://doi.org/10.1590/S0100-83582005000300004

Barbosa, J. C.; Maldonado Júnior, W. Software AgroEstat: Sistemas para análises estatísticas de ensaios agronômicos. Jaboticabal: Universidade Estadual Paulista, 2010. 141p.

Brachtvogel, E. L.; Pereira, F. R. da S.; Cruz, S. C. S.; Bicudo, J. S. Densidades populacionais de milho em arranjos espaciais convencional e eqüidistante entre plantas. Ciência Rural, v.39, p.2334-2339, 2009. https://doi.org/10.1590/S0103-84782009005000193

Brunini, R. G.; Turco, J. E. P. Growth of sugarcane (Sacharum ssp L.) in different production scenarios exhibitions and slopes. Ambiência, v.12, p.841-849, 2016. https://doi.org/10.5935/ambiencia.2016. Especial.09

Demétrio, C. S.; Fornasieri Filho, D.; Cazetta, J. O.; Cazetta, D. A. Desempenho de híbridos de milho submetidos a diferentes espaçamentos e densidades populacionais. Pesquisa Agropecuária Brasileira, v.43, p.1691-1697, 2008. https://doi.org/10.1590/S0100204X2008001200008

EMBRAPA - Empresa Brasileira de Pesquisa Agropecuária. Cultivo do milho. Brasília: Embrapa Informação Tecnológica, 2010. 86p.

EMBRAPA - Empresa Brasileira de Pesquisa Agropecuária. Sistema brasileiro de classificação de solos. Brasília: Embrapa Informação Tecnológica, 2013. 353p.

Farinelli, R.; Penariol, F. G.; Fornasieri Filho, D. Características agronômicas e produtividade de cultivares de milho em diferentes espaçamentos entre linhas e densidades populacionais. Científica, v.40, p.21-27, 2012. http://dx.doi.org/10.15361/1984-5529.2012v40n1p21+-+27

Galon, L.; Tironi, P. S.; Rocha, A. A.; Soares, R. E.; Concenço, G.; Alberto, M. C. Influência dos fatores abióticos na produtividade da cultura do milho. Revista Tropica: Ciências Agrárias e Biológicas, v.4, p.8-38, 2010.

IMEA - Instituto Mato-Grossense de Economia Agropecuária. Custo de produção de milho - Safra 2016/2017. Cuiabá: IMEA, 2016.7p.

Karlen, D. L.; Kasperbauer, M. J. Row orientation and configuration effects on canopy light spectra and corn growth. Applied Agricultural Research, v.4, p.41-56, 1989.

Kasperbauer, M. J.; Karlen, D. L. Plant spacing and reflected far-red light effects on phytochrome-regulated phtosynthate allocation in corn seedlings. Crop Science, v.34, p.1564-1569, 1994. https:// doi.org/10.2135/cropsci1994.0011183X003400060027x

Pereira, R. S. B. Caracteres correlacionados com a produção e suas alterações no melhoramento genético do milho (Zea mays L.). Pesquisa Agropecuária Brasileira, v.26, p.745-751, 1991.

Raij, B. van; Cantarella, H.; Quaggio, J. A.; Furlani, A. M. C. Recomendações de adubação e calagem para o Estado de São Paulo. 2.ed. Campinas: Instituto Agronômico, 1996. 255p. Boletim Técnico, 100

Silva, M. C. da; Gamero, C. A. Qualidade da operação de semeadura de uma semeadora-adubadora de plantio direto em função do tipo de martelete e velocidade de deslocamento. Revista Energia na Agricultura, v.25, p.85-102, 2010. https://doi.org/10.17224/ EnergAgric.2010v25n1p85-102 
Streck, N. A.; Lago, I.; Samboranha, F. K.; Gabriel, L. F.; Schwantes, A. P.; Schons, A. Temperatura-base para aparecimento de folhas e filocrono da variedade de milho BRS Missões. Ciência Rural, v.39, p.224-227, 2009. http://dx.doi.org/10.1590/S010384782009000100035
Uate, J. V.; Pinho, R. G. von; Cancellier, L. L.; Camilo, A.; Bernardo Júnior, L. A. Y. Épocas de semeadura e distribuição espacial de plantas na produção de milho. Revista Brasileira de Milho e Sorgo, v.14, p.346-357, 2015. http://dx.doi.org/10.18512/1980-6477/ rbms.v14n3p346-357 